\section{El Niño behind penguin deaths?}

SIR-In the South Atlantic Ocean in February 1986, large numbers of Rockhopper penguins (Eudyptes crestatus) were found dying along the coast of the Falkland Islands ${ }^{1.2}$. By late May 1986 3,000 penguins were found dead in one rookery. The two hypotheses put forward to explain this mortality of rockhopper penguins - competition for food with fishermen, and marine pollution from radioactivity $^{1.3}$ - are unconvincing ${ }^{3.4}$. Overfishing should not cause sudden, severe and widespread changes over a large area in the South Atlantic. The Gentoo penguin (Pygoscelis papua) and the magellanic penguin (Spheniscus magellanicus), which feed further inshore and often on fish were less affected, sug gesting food was still available. And there is no evidence that radioactivity caused penguins to die.

In February 1986, while penguins were dying in the Falkland Islands, Cape cormorants (Phalacrocorax capensis) off the coast of Southwest Africa deserted their nests ${ }^{5}$ and magellanic penguins along the Argentine coast from Punta Tombo to Cabo Virgenes fledged chicks and moulted as usual. The small rockhopper colony at Isla Pinguino also appeared normal. It was not until April 1986, that excessive mortality and malnourished penguins began appearing. Thousands of penguins were found dead along the Argentinian coast of Santa Cruz. In April, only live birds were seen at Cabo Domingo but in May 276 rockhopper and 10 magellanic penguins were found dead. About $500 \mathrm{~km}$ north, at Cabo Blanco, 294 rockhopper penguins were found dead in the period $4-9$ May. All were emaciated and most were moulting. Examination of eight of the most recentiy dead birds showed they had little or no fat, suggesting death by starvation. The contention that the penguins died from radioactivity leaking from sunken British submarines ${ }^{3}$ was not upheld by the background level of radioactivity found in their stomachs.

There is other evidence that suggests that the penguins died because food was unavailable. In Argentina, penguins were moulting in early May 1986, two to three months later than normal, as occurs when food is scarce or not available. Similarly, rockhopper penguins in the Falkland Islands, which normally moult and depart in April, were still present in late May. They may have been unable to gain sufficient weight to moult and, therefore, delayed both moulting and leaving. Furthermore there are several records of penguins being found north of their normal range in the South Atlantic in February to August 1986, suggesting birds wandered to other areas in search of food.

Presumably, the lack of food was caused by a change in oceanic conditions. The locations and timing of penguin mortality shows a large area was affected for several months. The South Atlantic had stronger westerly winds (poleward from 40 degrees South) from December 1985 to September 1986, than the average 1980 1983 winds $^{6}$. These strong winds should have intensified wind-driven inshore upwelling and benefited coastal species. Indeed, breeding magellanic and rockhopper penguins along the Argentine coast appeared normal. In the Falkland Islands, penguins fed closer to shore in 1986 than in $1985^{4}$. What could have caused abnormal oceanic conditions in the Atlantic in 1986?

In February and March 1986, the breeding success of seabirds in the Pacific was extremely low, as is typical during a $\mathrm{El}$ Niño Southern Oscillation (ENSO) in the Pacific Ocean ${ }^{7.8}$. Massive die-offs and reproductive failure of seabirds are common during ENSO events in the Pacific. Before the ENSO events along the coast of Peru, the Southeast trades blew more strongly than normal and upwelling was stronger than usual ${ }^{9}$. Strong westerly winds in the Atlantic may be the critical factor in changing offshore conditions in the South Atlantic. In both oceans a strong wind-driven upwelling system is perturbed by unusually strong surface winds.

During 1986, atmospheric conditions in the South Atlantic were peculiar: the southern summer of 1986 was unseasonably long and hot and the Falkland Islands had an influx of warm water speciest. These changes are consistent with a largescale warming. Mechanisms of atmospheric forcing in the tropical Atlantic analogous to the Pacific ENSO have been suggested and there are data showing the Benguela Current along Africa is affected $^{10}$.

I should therefore like to suggest that the ultimate cause of the extensive mortality of penguins in the South Atlantic Ocean in 1986 was an ENSO event.

P. Dee Boersma

Institute for Environmental Studies and Department of Zoology,

University of Washington,

Seattle, Washington 98195 , USA

\footnotetext{
1. Lyster, S. Falkland Island Fdn Newsl. 5. 2-4(1986)

Rich, V. Nature 322. 4 (1986)

Rich, V. Nature 322. $296(1986)$

3. Rich, V. Nature 322. 296 (1986).

5. Crawford, R.J.M., Williams. A.J. \& Crawford. P.B. S. Afr. J. Mar. 4. 119-123(1986).

6. Climate Diagnostics Bulletins (NOAA. Washington DC. January-September 1986)

Schreiber, R.W \& Schreiber. E.A. Climate Diagnostics Bulletin 7-8 (NOAA. Washington DC. March 1986).

Bowman. R.I. Climate Diagnostics Bulletin 8 (NOAA. Washington DC. April 1986).

Washington DC, April 1986).

9. Cane, M.A. Science 222, $1189-1195$ (1983)

0. Shannon, L.V., Boyd. A.J.. Brundrit, G.B. \& Taunton-
} Clark, J. J. mar. Res. 44, 495-520(1986).

\section{Publishers needed}

SIR-Wallace S. Broecker, a distinguished scientist in his own field, has like many others been led to the view that he can also solve problems in at least one other field - publishing (Nature 326, 207; 1987). Well ... I believe that Broecker's main argument is false. His error is not new. $\mathrm{He}$ says "I do not need a publisher because I can edit books cheaply by means of word processing, computer assistance for illustrations, etc...". Very true. Broecker can produce his book this way. The trouble is that publishers seek to design books that will appeal to readers as well as to the author, so that the readers buy it and so that it becomes their book.

This is why publishers desire to "dominate decisions about format, cover design, marketing and so on". It seems not to have occurred to the author that publishers may have some ideas about their trade. No doubt Broecker can also design a cover, provide the illustration and do the layout. I can also believe thiat he can fry eggs and buy biead, and sustain himself with this diet: he will probably produce a pamphlet next week denying the capacity of cooks and the ability of nutritionists in Homecooking for the Gourmet. Similarly with art: when you have seen one portrait, you have seen them all.

Publishing like any other industry expects a profit. I do not understand why Broecker thinks it wants a profit "above all". His "financial outlook" assumes that all the books will be sold: with this assumption, any financial outlook looks good.

But on one point I object very strongly: publishers should not need the help of "grants from charitable foundations" or (I might add) government subsidies, direct or indirect, to publish books. If Broecker expects "above all" to make a profit of $\$ 142,000$ with one book, he has to take some risk.

Philippe Boulanger

Pour la Science,

8 rue Férou,

75006 Paris, France

\section{But not female}

SIR-Your news article on the King Faisal International Prizes (Nature 326, 118 1987) contains the statement "On the other hand. of 14 science or medicine prize-winners so far, none has been female or Jewish". That is not correct. I am a co-winner of the King Faisal International Prize in Medicine (1984) and I am Jewish, whether or not it was known to the officials.

Department of Medicine,

Michael Field

College of Physicians \& Surgeons

of Columbia University,

New York. New York 10032, USA 